ABCD Arq Bras Cir Dig

2017;30(1):30-34

DOI: /10.1590/0102-6720201700010009

\title{
DETECTION OF OCCULT LYMPH NODE TUMOR CELLS IN NODE-NEGATIVE GASTRIC CANCER PATIENTS
}

\author{
Identificação de células tumorais ocultas em linfonodos de pacientes com câncer gástrico classificados como pno
}

Marina Alessandra PEREIRA ${ }^{1,2}$, Marcus Fernando Kodama Pertille RAMOS ${ }^{1,2}$, Andre Roncon DIAS ${ }^{\mathbf{1}, 2}$, Osmar Kenji YAGI, Sheila Friedrich FARAJ ${ }^{1,2}$, Bruno ZILBERSTEIN ${ }^{1,2}$, Ivan CECCONELLO ${ }^{1,2}$, Evandro Sobroza de MELLO ${ }^{1,2}$, Ulysses RIBEIRO-JR ${ }^{1,2}$

From the ${ }^{1}$ Hospital das Clínicas/Faculdade de Medicina and 'Instituto do Câncer, Universidade de São Paulo ('Hospital das Clínicas and ${ }^{2}$ Cancer Institute, University of São Paulo Medical School), São Paulo, SP, Brazil.

HEADINGS - Gastric cancer.
Micrometastasis. Lymph node metastasis. Immunohistochemistry.
ABSTRACT - Background: The presence of lymph nodes metastasis is one of the most important prognostic indicators in gastric cancer. The micrometastases have been studied as prognostic factor in gastric cancer, which are related to decrease overall survival and increased risk of recurrence. However, their identification is limited by conventional methodology, since they can be overlooked after routine staining. Aim: To investigate the presence of occult tumor cells using cytokeratin (CK) AE1/AE3 immunostaining in gastric cancer patients histologically lymph node negative ( $\mathrm{pNO}$ ) by H\&E. Methods: Forty patients (T1-T4NO) submitted to a potentially curative gastrectomy with D2 lymphadenectomy were evaluated. The results for metastases, micrometastases and isolated tumor cells were also associated to clinicopathological characteristics and their impact on stage grouping. Tumor deposits within lymph nodes were defined according to the tumor-node-metastases guidelines ( $7^{\text {th }}$ TNM). Results: A total of 1439 lymph nodes were obtained ( 36 per patient). Tumor cells were detected by immunohistochemistry in 24 lymph nodes from 12 patients (30\%). Neoplasic cells were detected as a single or cluster tumor cells. Tumor $(p=0.002)$, venous $(p=0.016)$, lymphatic $(p=0.006)$ and perineural invasions $(p=0.04)$, as well as peritumoral lymphocytic response $(p=0.012)$ were correlated to CK-positive immunostaining tumor cells in originally negative lymph nodes by $H \& E$. The histologic stage of two patients was upstaged from stage IB to stage IIA. Four of the 28 CK-negative patients $(14.3 \%)$ and three among 12 CK-positive patients $(25 \%)$ had disease recurrence $(p=0.65)$. Conclusion: The $\mathrm{CK}$-immunostaining is an effective method for detecting occult tumor cells in lymph nodes and may be recommended to precisely determine tumor stage. It may be useful as supplement to $H \& E$ routine to provide better pathological staging.

\section{Correspondência:}

Marina Alessandra Pereira

E-mail: ma.ap@hotmail.com

Fonte de financiamento: não há

Conflito de interesse: não há.

Recebido para publicação: Aceito para publicação:

DESCRITORES - Câncer gástrico. Micrometástases. Metástase linfonodal. Imunoistoquímica.
RESUMO - Racional: A presença de metástase em linfonodos é um dos indicadores prognósticos mais importantes no câncer gástrico. As micrometástases têm sido estudadas como fator prognóstico no câncer gástrico, sendo relacionadas à diminuição da sobrevida global e aumento do risco de recidiva da doença. Entretanto, sua identificação é limitada pela metodologia convencional, uma vez que podem não ser identificadas pela rotina histopatológica por meio da coloração de H\&E. Objetivo: Investigar a presença de células tumorais ocultas através de imunoistoquimica utilizando as citoqueratinas (CK) AE1/AE3 em pacientes com câncer gástrico com linfonodos histologicamente classificados como negativos por H\&E. Métodos: Quarenta pacientes (T1-T4N0) submetidos à gastrectomia potencialmente curativa com linfadenectomia D2 foram avaliados. A presença de metástases, micrometástases e células tumorais isoladas foram correlacionadas com características clínicopatológicas e impacto no estadiamento. Os depósitos tumorais nos linfonodos foram classificados de acordo com o sistema TNM (70 TNM). Resultados: Um total de 1439 linfonodos foi obtido ( 36 por paciente). Células tumorais foram detectadas por imunoistoquimica em 24 linfonodos de 12 pacientes (30\%). As células neoplásicas estavam presentes na forma isolada ou em cluster. Invasão tumoral $(p=0,002)$, venosa $(p=0,016)$, linfática $(p=0,006)$ e perineural $(p=0,04)$, assim como resposta linfocítica peritumoral $(p=0,012)$ foram correlacionadas com linfonodos CK-positivos que originalmente eram negativos à $\mathrm{H} \& \mathrm{E}$. Dois pacientes tiveram o estadiamento alterado, migrando do estádio IB para IIA. Quatro dos 28 CK-negativos (14,3\%) e três dos 12 CKpositivos (25\%) tiveram recorrência da doença $(p=0,65)$. Conclusão: $A$ imunoistoquimica é meio eficaz para a detecção de células tumorais ocultas em linfonodos, podendo ser recomendada para melhor determinar o estágio do tumor. Ela pode ser útil como técnica complementar à rotina de $\mathrm{H} \& \mathrm{E}$, de modo a fornecer melhor estadiamento patológico.

\section{INTRODUCTION}

Lymph node metastasis is considered one of the most important prognostic indicators in gastric carcinoma (GC), thus the number of positive lymph node (LN) is essential to stratify patients by stages and may useful for predicting patient survival $3,16,25,29,30,31$. Surgery with complete tumor removal, adequate free margins and regional lymphadenectomy is the best treatment option for resectable GC. It has been widely accepted that the procedure provides the best results in reduction of locoregional tumor recurrences and improvement of survival in 
patients with $\mathrm{GC}^{11,28}$.

Nevertheless, despite curative resection of their primary tumor, some patients with histologically node negative (pNO) GC based on conventional histological H\&E staining still have local or distant tumor recurrence ${ }^{11,17}$. Occult lymph node micrometastasis (LNmi) within regional LNs that is not detected by routine histological examination has been suspected to be a key causative factor of recurrence and metastasis in these patients ${ }^{17,32}$.

The aim of the present study was to identify the incidence of potentially relevant occult tumor cells in patients with pNO GC using cytokeratins immunostaining, and analyze their impact on stage grouping. The results for the presence of metastasis, micrometastasis and tumor deposits were also associated with clinicopathological characteristics.

\section{METHODS}

\section{Patients}

This study was approved by our institution ethics committee, and all patients signed the informed consent form before their inclusion in the study (CEP-FMUSP: 354/13).

Were retrospectively analyzed patients submitted to potentially curative resection with $\mathrm{D} 2$ lymphadenectomy for GC between 2009 and 2014 at Cancer Institute of University of São Paulo, São Paulo, SP, Brazil. The inclusion criteria were: radical gastrectomy with D2 lymphadenectomy, R0 resection, node-negative patients ( $\mathrm{pN} 0$ ) by $\mathrm{H} \& \mathrm{E}$ histopathologic routine examination, absence of distant metastasis, adequate archival tissue for analysis and the availability of complete clinicopathologic data.

Clinicopathological characteristics about tumor and disease recurrence were collected from the hospital gastric cancer data bank.

All appraisal cases samples were obtained surgically from patients at the gastrointestinal surgery service and were histopathologically examined.

\section{Anatomopathological evaluation}

Primary tumors and LNs were fixed in $10 \%$ formalin solution and embedded in paraffin. Processing of the resection specimens was done using a standardized protocol. All LN were routinely stained with H\&E and were classified as pN0. For histological examination and diagnostic confirmation of selected cases, the original $\mathrm{H} \& \mathrm{E}$ sections of all LNs were re-analysed by pathologists from the service.

The presence or absence of LNmi was examined using a representative sections obtained from the total inclusion of nodal structure.

Detection of tumor cells by immunohistochemistry

The LNs from pNO cases were re-evaluated by immunohistochemistry (IHC) using antibodies against human cytokeratins (CK) AE1/AE3 (Dako Corporation, Carpinteria, CA 93013 USA) in order to identify the cytokeratins of malignant cells inside LNs. The antibody cocktail AE1/AE3 is specific for a range of human cytokeratins in epithelial cells and does not react with lymphoid tissue.

Tissue sections from paraffin blocks were deparaffinized with xylene and rehydrated with graded ethanol dewaxed. After, the histologic sections were subjected to heat- induced antigen retrieval with citrate buffer solution $\mathrm{pH}$ 6.0) in a steamer for $30 \mathrm{~min}$. Endogenous peroxidase was blocked with $\mathrm{H}_{2} \mathrm{O}_{2}(6 \%)$, and sections were incubated overnight with primary antibodies at $4^{\circ} \mathrm{C}$. The secondary antibody was applied and followed by the application of peroxidase-labeled streptovidin (Novolink - Novocastra Laboratories, Newcastle, UK). The reaction products were visualized with diaminobezidine as the chromogen and sections were counterstained with Harris's hematoxylin. Tris-buffered saline was used as a negative control instead of primary antibody for negative controls.

Microscopic analysis was carried out using a conventional light microscope. Dark brown insolvable precipitate was formed peripherically around malignant cells, corresponding to cytokeratin-positive cells. The CK AE1/AE3-positive cells in the LNs were compared with the same sections stained with H\&E.

\section{Definition of lymph node positive findings}

Tumor deposits within LNs were defined and classified according to the $7^{\text {th }}$ edition of the TNM guidelines. The distinction among metastasis, micrometastasis and isolated tumor cells (ITC) was based on the size of the metastastatic tumor foci.

Positive LN metastasis was defined when tumor cells measuring more than $2.0 \mathrm{~mm}$ were found. Micrometastasis was defined when tumor cells clusters measures between 0.2-2.0 $\mathrm{mm}$. Metastasis or micrometastasis detected by morphological techniques, such as H\&E staining or immunohistochemistry, should be classified as pN1 and pN1 micrometastasis, respectivelly, and included in the disease staging. ITC are single tumor cells or small clusters of cells measuring $<0.2 \mathrm{~mm}$ in greatest dimension. Patients with ITC in LN are staged as pNO(i+), but do not change the TNM stage. Patients with some LN tumor deposits (micrometastasis, ITC or cluster) were defined as a "CKpositive" and patients without tumors cells in LN were defined as "CK-negative" for comparison analysis

\section{Statistical analysis}

The clinicopathological variables of cases (CK-positive group) and controls (CK-negative group) were compared using the Fisher's exact test or Chi-square test. All tests were two-sided and a p-value less than 0.05 was considered statistically significant. Statistical analysis was performed using SPSS software, version 18.0 (SPSS Inc, Chicago, IL).

\section{RESULTS}

Were reviewed 255 GC cases and 111 patients were classificated as pN0. The mean age of the patients was 64.6 years (26-84), and the male/female ratio was 1.5 (3:2). A total of 1439 LNs was obtained. The average number of LNs dissected per patient was 36. Among these 111 cases, a consecutive series of 40 patients were included in this study. The cases were selected as follows: 11 pT1, 11 pT2, 11 pT3 and 7 pT4 tumors. All original H\&E slides were reviewed and pNO were confirmed by two distinct pathologists.

\section{Detection of lymph node tumor cells}

A total of 29 LNs obtained from 12 (30\%) patients contained tumor cells that were immunopositive for CK by immunohistochemistry staining. Two patients were pT2, five pT3 and five pT4. Micrometastasis were detected in 
three nodes from two pT2 patients (5\%). The number of LNs involved ranged from 1-9 per patient, with an average of 2.4. In addition, it was seen among CK-positive group that the microinvolvement occurred as single-cell type in nine patients and as cell cluster-type in all 12 patients (Figure 1).

Two patients (T2 stage) with GC diagnosed as free of metastasis by ordinary H\&E staining were re-staged because had evidence of micrometastasis in their regional LNs on the basis of immunohistochemistry analysis, migrating from stage IB to IIA.

Occult tumor cells vs. clinicopathological parameters

No significant difference was noted between CK-positive and CK-negative groups in the analysis of clinicopathological data, including: patient age, gender, tumor location, histological type and average number of dissected LNs. Although there was no significant relationship between tumor size, the average of CK-positive group $(4.0 \mathrm{~cm})$ was larger than negative group $(2.8 \mathrm{~cm})$

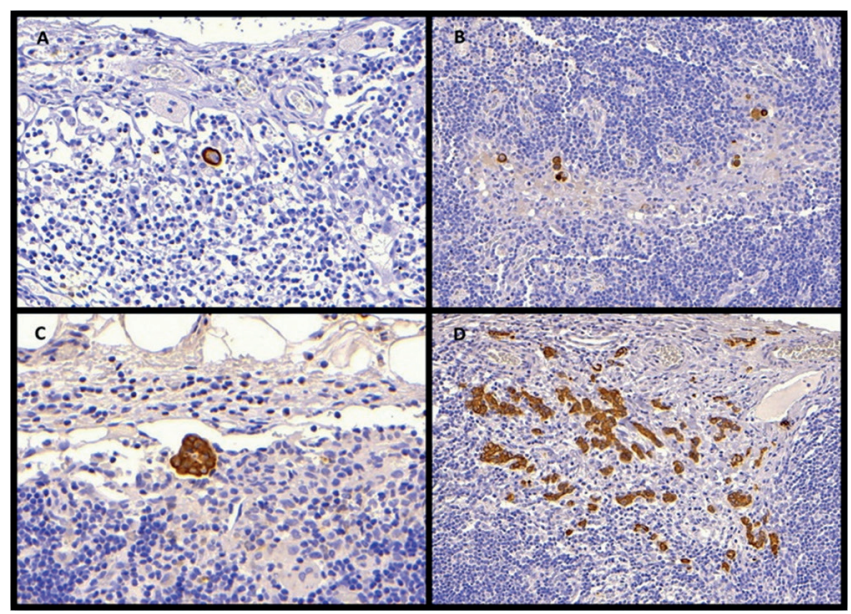

FIGURE 1 - Cytokeratin (AE1/3) immunostaining in lymph nodes: A) isolated tumor cell (ITC); B) multiple cancer cells in the form of ITC; C) tumor cells in the form of clustered cancer cells; D) micrometastasis in the form of multiple cluster cells

Lymph node CK positive was significantly associated with tumor depth of wall invasion $(p=0.002)$, venous $(p=0.016)$, lymphatic $(p=0.006)$ and perineural invasions $(p=0.04)$ and peritumoral lymphocytic response $(p=0.012)$. The incidence of LNs tumor cells according to tumor depth was as follows: $0 \%$ in pT1, $18 \%$ pT2, $45 \%$ pT3, $71 \%$ pT4. Two CK-positive patients had neoadjuvant therapy. Table 1 shows the clinicopathologic characteristics of patients with LN CK-positive and CK-negative.

The median length of postoperative follow-up was 33 months, ranging from 2-72 months. During the followup period, a total of seven cases of cancer recurrence were reported. Although not statistically significant, the recurrence was more common in CK-positive patients $(3 / 12,25 \%)$ than in CK-negative group (4/28, $14.3 \%)$. Of the three CK-positive patients with disease recurrence, one was PT3 and two were pT4. In all of them only tumor cluster-type and single-cell were observed.
TABLE 1 - Clinicopathologic characteristics of 40 GC patients pNO by H\&E with and without CK-positive tumor cells in $\mathrm{LN}$ by immunostaining

\begin{tabular}{|c|c|c|c|}
\hline \multirow[t]{2}{*}{ Variable } & CK-negative & CK-positive & $p$ \\
\hline & $\mathrm{n}=28(\%)$ & $\mathrm{n}=12(\%)$ & \\
\hline \multicolumn{3}{|l|}{ Gender } & 0.72 \\
\hline Female & $12(49.9)$ & $4(33.3)$ & \\
\hline Male & $16(57.1)$ & $8(66.7)$ & \\
\hline \multicolumn{3}{|l|}{ Tumor location } & 0.14 \\
\hline Proximal & $8(28.6)$ & $2(16.7)$ & \\
\hline Middle & $9(32.1)$ & $3(25)$ & \\
\hline Distal & $10(35.7)$ & $4(33.3)$ & \\
\hline Anastomosis & $0(0)$ & $2(16.7)$ & \\
\hline NA & $1(3.6)$ & $1(8.33)$ & \\
\hline \multicolumn{3}{|l|}{ Size of the lesion } & 0.18 \\
\hline Mean $(\mathrm{cm})$ & 2.8 & 4.0 & \\
\hline$<4.5 \mathrm{~cm}$ & $18(64.3)$ & $5(41.7)$ & \\
\hline$\geq 4.5 \mathrm{~cm}$ & $10(35.7)$ & $7(58.3)$ & \\
\hline \multicolumn{3}{|l|}{ Borrmann type } & 0.38 \\
\hline I & $5(17.9)$ & $0(0)$ & \\
\hline II & $3(10.7)$ & $1(8.33)$ & \\
\hline III & $17(60.7)$ & $10(83.3)$ & \\
\hline IV & $1(3.6)$ & $1(8.33)$ & \\
\hline Undetermined & $2(7.2)$ & $0(0)$ & \\
\hline \multicolumn{3}{|l|}{ Lauren's classification } & 1 \\
\hline Intestinal-type & $17(60.7)$ & $7(58.3)$ & \\
\hline Diffuse-type & $9(32.1)$ & $4(33.3)$ & \\
\hline NA & $2(7.2)$ & $1(8.33)$ & \\
\hline \multicolumn{3}{|c|}{ Grade of histological differentiation } & 1 \\
\hline $\begin{array}{l}\text { G1/G2 - well/moderate } \\
\text { differentiated }\end{array}$ & $13(46.4)$ & $6(50)$ & \\
\hline G3 - poorly differentiated & $15(53.6)$ & $6(50)$ & \\
\hline \multicolumn{3}{|l|}{ Depth of invasion } & 0.355 \\
\hline Early & $11(39.3)$ & $0(0)$ & \\
\hline Advanced & $17(60.7)$ & $12(100)$ & \\
\hline \multicolumn{3}{|l|}{ Pathologic T stage } & 0.002 \\
\hline $\mathrm{T} 1 / \mathrm{T} 2$ & $20(71.4)$ & $2(16.7)$ & \\
\hline T3 / T4 & $8(28.6)$ & $10(83.3)$ & \\
\hline \multicolumn{4}{|l|}{ Number of LN evaluated } \\
\hline Mean & 36.5 & 34.7 & 0.41 \\
\hline$\leq 25$ & $5(17.9)$ & $4(33.3)$ & \\
\hline$>25$ & $23(82.1)$ & $8(66.7)$ & \\
\hline \multicolumn{3}{|l|}{ Venous invasion } & 0.016 \\
\hline Absent & $23(82.1)$ & $5(41.7)$ & \\
\hline Present & $4(14.3)$ & $7(58.3)$ & \\
\hline NA & $1(8.33)$ & $0(0)$ & \\
\hline \multicolumn{3}{|l|}{ Lymphatic invasion } & 0.006 \\
\hline Absent & $20(71.4)$ & $3(25)$ & \\
\hline Present & $7(25)$ & $9(75)$ & \\
\hline NA & $1(8.33)$ & $0(0)$ & \\
\hline \multicolumn{3}{|l|}{ Perineural invasion } & 0.040 \\
\hline Absent & $19(67.8)$ & $4(33.3)$ & \\
\hline Present & $8(28.6)$ & $8(66.7)$ & \\
\hline NA & $1(8.33)$ & $0(0)$ & \\
\hline \multicolumn{4}{|l|}{$\begin{array}{l}\text { Lymphocytic peritumoral } \\
\text { response }\end{array}$} \\
\hline Mild / nearly absent & $9(32.1)$ & $9(75)$ & 0.012 \\
\hline Moderate / Intense & $17(60.7)$ & $2(16.7)$ & \\
\hline NA & $2(7.2)$ & $1(8.33)$ & \\
\hline \multicolumn{3}{|l|}{ Neoadjuvant chemotherapy } & 0.209 \\
\hline Yes & $1(8.33)$ & $2(16.7)$ & \\
\hline No & $27(96.4)$ & $10(83.3)$ & \\
\hline Disease Recurrence & & & 0.4 \\
\hline Yes & $4(14.3)$ & $3(25)$ & \\
\hline No & $24(85.7)$ & $9(75)$ & \\
\hline
\end{tabular}

\section{DISCUSSION}

Lymph node metastasis is known as an important prognostic factor in GC, once the curative surgery with LN dissection admittedly reduces the risk of recurrence ${ }^{17}$. For this reason, studies have been conducted in order to improve the "N" stage evaluation, including implementation of "lymph nodes revealing solution" to increase the amount of retrieved nodes and the addition of complementary methods for tumor cells detection in the histopathological diagnostic routine ${ }^{7,8}$

The histologic examination using $\mathrm{H} \& \mathrm{E}$ staining is the gold-standard for lymph node metastasis diagnosis. However, 
sometimes the LN status determined through conventional histological methods does not adequately reflect the prognosis ${ }^{15}$. The routine method of serial sections can miss gastric tumor cells due the heterogeneous distribution of metastatic foci avoiding the examination to access the full depth of $\mathrm{LN}$ involvement by the neoplasia ${ }^{2,21,22}$ Consequently, recurrence can occur in node negative patients, and it is possible that such disease relapse originates from otherwise undetected micrometastic cancer cells. Maehara et al. ${ }^{17}$ was one of the first researchers to highlight that even after curative resection of an early gastric cancer, some patients have recurrence, because they have occult micrometastasis in perigastric LNs at the time of original diagnosis ${ }^{17}$.

In this retrospectively designed study, were performed immunohistochemistry staining for cytokeratin (CKAE1/AE3) on LNs that remained negative for macrometastasis based on conventional $\mathrm{H} \& \mathrm{E}$ staining to evaluate the incidence of $\mathrm{LN}$ involvement in pNO GC and their impact on stage grouping, determining whether other clinicopathologic parameters might be associated with their occurrence. Cytokeratin (CK) is a basic component of the cytoskeleton of epithelial cells and they are reliably expressed by tumor cells. Through the use of specific antibodies, immunohistochemistry staining may facilitates the detection with the advantage that it can morphologically identify a single cancer cell or clusters of cancer cells that could readily be missed by routine histological examination 27,31 . Moreover, the sections depth from paraffin block for performing immunohistochemistry can make the tumor deposit more evident in the LNs. This method is useful especially in the Lauren's diffuse type, where it is difficult to detect when only a small number of tumor cells are present in the LN. Furthemore, compared with nodal metastases detected by H\&E staining, micrometastasis detected by immunohistochemistry in most cases manifest as discrete or small clustered cancer cells in the medullar and marginal sinus of the $\mathrm{LN}^{4,5}$.

In contrast to immunohistochemistry, molecular markers allow analysis of the entire LN in one reaction, thus reducing the time needed for screening. Recent studies with GC demonstrated an increase in the detection of LNmi using reverse transcription-polymerase chain reaction (RT-PCR) assays for carcinoembryonic antigen or CK20 messenger RNAs ${ }^{13}$. However, false-positive results are allegedly common, since the specificity might be reduced by illegitimate expression of the respective marker gene from normal LN cells ${ }^{23}$.

According to the $7^{\text {th }}$ TNM classification, LNmi detected by morphological techniques, such as H\&E staining or immunohistochemistry, should be included in the staging of disease. In this sense, it is important to note that while many studies basically define micrometastasis as the presence of a single ITC or small cluster of gastric tumor cells identified by immunohistochemistry and not visualized by $H \& E$, this study examined the incidence of LNs tumor cells on the basis of the TNM criteria, according to the size of the tumor deposit. In the present study, 12 cases (30\%) with occult tumor cells were identified among 40 surgically treated pNO GC. This frequency is consistent with those reported in the literature, where undetected tumor cells corresponding to $10-36 \%$ of pNO patients ${ }^{22}$.

Generally, the presence of LN tumor cells has been associated to particular clinicopathological characteristics. Patients with more advanced pT category tend to have a higher incidence of micrometastasis compared with pT1N0 tumors ${ }^{17}$. Micrometastasis detected by immunohistochemistry were reported to occur in $10.7 \%$ of $\mathrm{T} 1^{20}$ and in $20 \%$ of
T2-T4 ${ }^{31}$ of previous node-negative GC patients. In this series, all T1 patients had LNs CK-negative, while $41 \%$ of T2-T4 had LNs CK-positive. The present investigation showed that, besides the depth of wall invasion, LN occult involvement was significantly associated with advanced disease stage, lymphocyte peritumoral response, perineural and lymphovascular invasion, similar to other studies in the literature. Reports of micrometastasis incidence of $66.7 \%$ and $26.8 \%$ for patients with and without lymphatic invasion, respectively, reveal a significantly higher incidence of this characteristic in this group of patients $2,4,5,7$.

While some authors suggest micrometastasis association with tumor size, grade of histological differentiation (G2) G3) and Lauren's diffuse histology 4,5,11,12,26, these results didn't find any differences in LN involvement with respect to these characteristic. However, was observed that in the CK-positive group tumor tends to be larger than in the CK-negative group (4.0 vs. $2.8 \mathrm{~cm})$.

Interesting, although neoadjuvant chemotherapy is able to eradicate the occult disease before surgery ${ }^{10}$, two of three patients with neoadjuvant therapy had CK-positive LNs, showing that chemotherapy or radiotherapy may not necessarily eliminate the micrometastasis.

In this study, was found CK-positive tumor cells in 29 of the 1439 perigastric LN. The incidence of nodal involvement increased to $30 \%$ by immunohistochemistry with CKAE1/3, and $5 \%$ of patients which had previously been classified as $\mathrm{pNO}$ by conventional H\&E stain were re-staged to had evidence of micrometastasis in their regional LNs on the basis of immunohistochemistry analysis (stage IB to IIA). Although LNmi change the stage of the disease, one of the main points of debate still concerns to their clinical significance.

Recent studies have been conducted focusing on the significance and clinical importance of micrometastasis detection. In general, the presence of disseminated tumor cells in "tumor-free" lymph nodes has been associated with a poorer postoperative prognosis. However, there is no consensus as to the impact of LNmi on survival of patients with $\mathrm{GC}^{2,12,15,22}$.

Most authors agree that there is significant difference in prognostic and survival among patients with and without LNmi $2,7,17,26,31$. Yasuda et al. ${ }^{31}$ demonstrated that LNmi is an independent prognostic indicator for T2-T3pNO GC and the number and level of $\mathrm{LNmi}$ were strongly associated with survival time $(66 \% \text { vs. } 95 \%)^{31}$. A significantly lower survival rates was also observed by Dell'Aquila Jr et al. ${ }^{7}$, that found micrometastasis in 15 of 28 T1-T4N0 CG patient (2-year survival rate, $21,5 \%$ vs. $62,9 \%$ ), showing that micrometastasis are an important risk factor for recurrence in $\mathrm{GC}$, in a context of radical D2 lymphadenectomy ${ }^{7}$. Simillarly, Ru et al. ${ }^{26}$ results showed that the recurrence rate was significantly higher in the micrometastasis group than in the non-micrometastasis group ${ }^{26}$

However, others reports support the hypothesis that micrometastasis detection by immunohistochemistry would not offer a significant benefit over conventional pathologic in stratifying patients for planning appropriate adjuvant therapy and for prognostic grouping in clinical stages ${ }^{6,9,19,20}$. Whether these detected cancer cells can proliferate or if they can be removed by the host's immune response is still unknown ${ }^{4,5,22}$. Morgagni et al. ${ }^{19,20}$ found no prognostic relevance in micrometastasis detected by immunohistochemistry in T1N0 tumors (89\% vs. 94\%), even in a long postoperative follow-up of 10 years. Furthermore, the clinical evaluation of LNmi is somewhat difficult, because of the differences in 
study designs and methods of detection, such as the sample size, tumor stage of patients, number of retrieved LNs based on the area of LN dissection, use of immunohistochemistry or other methods, types of antibodies used and, principally, the definition of micrometastasis 9,22,29.

Some studies have investigated the role of LNmi in the adoption of adjuvant therapies and, especially, its clinical impact in applying minimally invasive treatment. An accurate intraoperative diagnosis of occult LN involvement would be essential particularly in defining criteria for limited surgical dissection, including endoscopic mucosal resection or endoscopic submucosal dissection, and sentinel node navigation surgery. Micrometastasis diagnosis may help to guide the area of appropriate LN dissection, allowing a tailored lymphadenectomy for the patient. Additionally, a better diagnostic definition of micrometastasis may also help to distinguish the category of pNO (micrometastasis +) patients with potential benefit of postoperative adjuvant therapy ${ }^{1,2,11,15,18,23}$

In this study, was found a higher incidence of recurrence of the disease in CK-positive group than in the CK-negative group ( $25 \%$ vs. $14.3 \%$ ), but this was not statistically significant. This finding may be justified due to the low number of patients involved in the study with a short period of followup. These initials results encourage our group to extend the analyses to a larger number of patients to better clarify the clinical significance of CK-positive LNs in GC patients.

\section{CONCLUSION}

The CK-immunostaining is an effective method for detecting occult tumor cells in lymph nodes and may be recommended as supplement to $H \& E$ routine to refine pathological staging in GC. Due to its association with characteristics related to a worse prognosis, the identification of tumor cells in lymph nodes may be useful as one additional information for follow-up and risk factor for recurrent gastric cancer.

\section{REFERENCES}

1. Aikou T, Higashi H, Natsugoe $S$, Hokita S, Baba M, Tako S. Can sentine node navigation surgery reduce the extent of lymph node dissection in gastric cancer? Ann Surg Oncol 2001; 8(9 Suppl):90S-3S.

2. Arigami T, Uenosono $Y$, Yanagita $S$, Nakajo A, Ishigami S, Okumura $\mathrm{H}$, Kijima $Y$, Ueno $S$, Natsugoe S. Clinical significance of lymph node micrometastasis in gastric cancer. Ann Surg Oncol 2013; 20(2):515-21.

3. Barchi LC, Jacob CE, Bresciani CJ, Yagi OK, Mucerino DR, Lopasso FP, Mester M, Ribeiro-Júnior U, Dias AR, Ramos MF, Cecconello I, Zilberstein B. Minimally invasive surgery for gastric cancer: time to change the paradigm. Arq Bras Cir Dig. 2016 Apr-Jun;29(2):117-20. A

4. Cai J, Ikeguchi M, Maeta M, Kaibara N, Sakatani T. Clinicopathological value of immunohistochemical detection of occultinvolvementin PT3NO gastric cancer. Gastric Cancer 1999; 2:95-100.

5. Cai J, Ikeguchi M, Tsujitani S, Maeta M, Liu J, Kaibara N. Significant correlation between micrometastasis in the lymph nodes and reduced expression of E-cadherin in early gastric cancer. Gastric Cancer 2001; 4:66-74.

6. Choi HJ, Kim YK, Kim YH, Kim SS, Hong SH. Occurrence and prognostic implications of micrometastases in lymph nodes from patients with submucosal gastric carcinoma. Ann Surg Oncol. 2002; 9(1):13-9.

7. Dell'Aquila Jr. NF, Lopasso FP, Falzoni R, Iriya K, Gama-Rodrigues J. Prognostic significance of occult lymph node micrometastasis in gastric cancer: a histochemical and immunohistochemical study based on 1997 UICC TNM and 1998 JGCA classifications. ABCD Arq Bras Cir Dig 2008: 21(4):164-9.

8. Dias AR, Pereira MA, Mello ES, Zilberstein B, Cecconello I, Ribeiro Junior $U$. Carnoy's solution increases the number of examined lymph nodes following gastrectomy for adenocarcinoma: a randomized trial. Gastric Cancer 2014 Nov 20. [Epub ahead of print]
9. Fukagawa T, Sasako M, Mann GB, Sano T, Katai H, Maruyama K, Nakanishi $Y$, Shimoda T. Immunohistochemically detected micrometastases of the lymphnodesin patientswith gastriccarcinoma. Cancer2001;92(4):753-60.

10. Huang JY, Xu YY, Li M, Sun Z, Zhu H, Song YX, Miao ZF, Wu JH, XU HM. The prognosticimpact ofoccultlymphnodemetastasisinnode-negative gastric cancer: a systematic review and meta-analysis. Ann Surg Oncol 2013; 20(12):3927-34.

11. Ishida K, Katsuyama T, Sugiyama A, Kawasaki S. Immunohistochemical evaluation of lymph node micrometastases from gastric carcinomas. Cancer 1997; 79(6):1069-76.

12. JeuckTL,WittekindC.Gastriccarcinoma:stagemigrationbyimmunohistochemically detected lymphnodemicrometastases. Gastric Cancer2015;18(1):100-8.

13. Kubota K, Nakanishi H, Hiki N, Shimizu Z, Tsuji E, Yamaguchi H, Mafune K, Tange T, Tatematsu M, Kaminishi M. Quantitative detection of micrometastases in the lymph nodes of gastric cancer patients with real-time RT-PCR: a comparative study with immunohistochemistry. Int J Cancer 2003; 105(1):136-43.

14. Lee CM, Cho JM, Jang YJ, Park SS, Park SH, Kim SJ, Mok YJ, Kim CS, Kim $\mathrm{JH}$. Should lymph node micrometastasis be considered in node staging for gastric cancer? The significance of lymph node micrometastasis in gastric cancer. Ann Surg Oncol 2015; 22(3):765-71.

15. Lee E, Chae Y, Kim I, Choi J, Yeom B, Leong AS. Prognostic relevance of immunohistochemicallydetectedlymphnodemicrometastasisin patients with gastric carcinoma. Cancer 2002; 94(11):2867-73.

16. Lins RR, Oshima CT, Oliveira LA, Silva MS, Mader AM, Waisberg J. Expression of e-cadherin and wnt pathway proteins betacatenin, APC, TCF-4 and survivin in gastric adenocarcinoma: clinical and pathological implication. Arq Bras Cir Dig. 2016 Nov-Dec;29(4):227-231.C

17. Maehara Y, Oshiro T, Endo K, Baba H, Oda S, Ichiyoshi Y, Kohnoe S, SugimachiK. Clinical significance of occultmicrometastasis lymph nodes from patients with early gastric cancer who died of recurrence. Surgery 1996; 119(4):397-402.

18. Matsumoto M, NatsugoeS, IshigamiS, NakashimaS, Nakajo A, Miyazono F, Hokita S, Takao S, Eizuru Y, Aikou K. Lymph node micrometastasis and lymphatic mapping determined by reverse transcriptase-polymerase chain reaction in pNO gastric carcinoma. Surgery 2002; 131(6):630-5.

19. Morgagni P, Saragoni L, Folli S, Gaudio M, Scarpi E, Bazzocchi F, Marra GA, Vio A. Lymph node micrometastases in patients with early gastric cancer: experience with 139 patients. Ann Surg Oncol 2001;8(2):170-4. 20. Morgagni P, Saragoni L, Scarpi E, Zattini OS, Zaccaroni A, Morgagni A, Bazzocchi F. Lymph node micrometastases in early gastric cancer and their impact on prognosis. World J Surg 2003; 27(5):558-61.

21. Natsugoe $S$, Aikou T, Shimada M, Yoshinaka H, Takao S, Shimazu H, Matsushita Y. Occult lymph node metastasis in gastric cancer with submucosal invasion. Surg Today 1994; 24(10): 870-5.

22. Natsugoe S, Arigami T, Uenosono Y, Yanagita S, Nakajo A, Matsumoto M, Okumura H, Kijima Y, Sakoda M, Mataki Y, Uchikado Y, Mori S, Maemura $\mathrm{K}$, Ishigami S. Lymph node micrometastasis in gastrointestinal tract cancer-a clinical aspect. Int J Clin Oncol 2013; 18(5):752-61.

23. Ohgami M, Otani Y, Kumai K, Kubota T, Kim Yl, Kitajima M. Curative laparoscopic surgery for early gastric cancer: fiveyears experience. World J Surg 1999; 23(2):187-92.

24. Okada Y, Fujiwara Y, Yamamoto $H$, Sugita $Y$, Yasuda T, Doki Y, Tamura S, Yano M, Shiozaki H, Matsuura N, Monden M. Genetic detection of lymph node micrometastases in patients with gastric carcinoma by multiple-marker reverse transcriptase-polymerase chain reaction assay. Cancer 2001; 92(8): 2056-64.

25. Ramagem CA, Linhares M, Lacerda CF, Bertulucci PA, Wonrath D, de OliveiraAT.Comparison oflaparoscopictotal gastrectomyandlaparotomic total gastrectomy for gastric cancer. Arq Bras Cir Dig. 2015;28(1):65-9.B

26. Ru Y, Zhang L, Chen Q, Gao SG, Wang GP, Qu ZF, Shan TY, Qian N, Feng $\mathrm{XS}$. Detection and clinical significance of lymph node micrometastasis in gastric cardia adenocarcinoma. J Int Med Res 2012; 40(1):293-9.

27. Saito H, Osaki T, Murakami D, Sakamoto T, Kanaji S, Ohro S, Tatebe S, Tsujtani S, Ikeguchi M. Recurrence in early gastric cancer - Presence of micrometastasis in lymph node of node negative early gastric cancer patient with recurrence. Hepatogastroenterology 2007; 54(74):620-4.

28. Siewert JR, Bottcher K, Roder JD, Busch R, Hermanek P, Meyer HJ and the German Gastric Cancer Study Group. Prognostic relevance of systematic lymph node dissection in gastric carcinoma. Br J Surg 1993; 80(8):1015-1018.

29. Siewert JR, Bottcher K, Stein HJ, Roder JD. Relevant prognostic factors in gastric cancer: ten-year results of the German Gastric Cancer Study. Ann Surg 1998; 228(4):449-61.

30. Siewert JR, Kestlmeier R, Busch R, Böttcher K, Roder JD, Müller J, Fellbaum C, Höfler $\mathrm{H}$. Benefits of D2 lymph node dissection for patients with gastric cancer and pN0 and pN1 lymph node metastases. Br J Surg 1996; 83(8):1144-7.

31. YasudaK,AdachiY,ShiraishiN, InomataM, TakeuchiH, KitanoSI.Prognostic effect oflymph node micrometastasis in patients with histologicallynode negative gastric cancer. Ann Surg Oncol 2002; 9(8):771-4.

32. YonemuraY, EndoY, Hayashil, KawamuraT, YunHY, BandouE.Proliferative activity of micrometastases in the lymph nodes of patients with gastric cancer. Br J Surg. 2007; 94(6):731-6. 